\title{
A study of the potential anticancer activity of Mangifera zeylanica bark: Evaluation of cytotoxic and apoptotic effects of the hexane extract and bioassay-guided fractionation to identify phytochemical constituents
}

\author{
MERAN KESHAWA EDIRIWEERA ${ }^{1}$, KAMANI HEMAMALA TENNEKOON ${ }^{1}$, \\ SAMEERA RANGANATH SAMARAKOON ${ }^{1}$, IRA THABREW ${ }^{1}$ and EGODAGE DILIP DE SILVA ${ }^{2}$ \\ ${ }^{1}$ Institute of Biochemistry, Molecular Biology and Biotechnology, University of Colombo; \\ ${ }^{2}$ Department of Chemistry, Faculty of Science, University of Colombo, Colombo 00300, Sri Lanka
}

Received November 29, 2014; Accepted November 26, 2015

DOI: $10.3892 / 01.2016 .4087$

\begin{abstract}
The present study investigated the potential anticancer activity of the bark of Mangifera zeylanica, an endemic plant in Sri Lanka that has been traditionally used for cancer therapy. Cytotoxic and apoptotic effects were investigated in vitro using sulphorodamine assay, acridine orange and ethidium bromide staining, caspase- 3 and -7 activity, DNA fragmentation and reverse transcription-quantitative polymerase chain reaction in estrogen receptor positive MCF-7 and triple-negative MDA-MB-231 breast cancer cell lines, SKOV-3 ovarian cancer cell line and MCF-10A normal mammary epithelial cells. Hexane extract demonstrated increased levels of cytotoxicity in cancer cells $\left(\mathrm{IC}_{50}, 86.6-116.5 \mu \mathrm{g} / \mathrm{ml}\right)$ compared with normal cells $\left(\mathrm{IC}_{50}\right.$, $217.2 \mu \mathrm{g} / \mathrm{ml})$. Chloroform extract demonstrated increased cytotoxicity to normal cells $\left(\mathrm{IC}_{50}, 92.9 \mu \mathrm{g} / \mathrm{ml}\right)$ compared with cancer cells $\left(\mathrm{IC}_{50}, 280.1-506.5 \mu \mathrm{g} / \mathrm{ml}\right)$. Exposure to the hexane extract led to morphological changes characteristic of apoptosis and DNA fragmentation in the three cancer cell lines. Caspase- 3 and -7 were significantly activated in MDA-MB-231 and SKOV-3 cells, indicating the occurrence of caspase-dependent apoptosis in these cells, and caspase-independent apoptosis in MCF-7 cells. Furthermore, upregulation of proapoptotic Bcl-2-associated $\mathrm{X}$ protein occurred in the three cancer cell lines, and antiapoptotic survivin was downregulated in MCF-7 and SKOV-3 cells; by contrast, tumor protein 553 was upregulated only in MCF-7 cells, suggesting
\end{abstract}

Correspondence to: Professor Kamani Hemamala Tennekoon, Institute of Biochemistry, Molecular Biology and Biotechnology, University of Colombo, 90 Cumaratunga Munidasa Mawatha, Colombo 00300, Sri Lanka

E-mail:kamani@ibmbb.cmb.ac.lk

Key words: Mangifera zeylanica, anticancer activity, cytotoxicity, apoptosis, phytochemical constituents, breast cancer, ovarian cancer p53-mediated apoptosis in MCF-7 cells and p53-independent apoptosis in the remaining cancerous cell lines. In addition, fraction $\mathrm{M}_{1}$ obtained from bioactivity-guided fractionation of the hexane extract demonstrated increased cytotoxicity in cancer cells $\left(\mathrm{IC}_{50}, 15.4-38.7 \mu \mathrm{g} / \mathrm{ml}\right)$ compared with normal cells $\left(\mathrm{IC}_{50}, 114.6 \mu \mathrm{g} / \mathrm{ml}\right)$, with the highest cytotoxicity observed in MDA-MB-231 triple-negative breast cancer cells. The hexane extract of $M$. zeylanica bark contained polyphenols and flavonoids, and caused free radical scavenging activity. Its gas chromatography-mass spectrometry profile revealed the presence of long-chain hydrocarbons, including $\beta$-sitosterol and $\beta$-amyrin. Fraction $\mathrm{M}_{1}$ contained seven unknown compounds and a small number of known non-cytotoxic compounds. Collectively, results obtained in the present study indicate that the hexane extract of M. zeylanica bark mediates cytotoxic activities through induction of apoptosis in three cancer cell lines; thus, the hexane extract may be used to isolate novel anti-cancer compounds.

\section{Introduction}

Breast cancer accounts for almost $1 / 4$ of all cancers diagnosed in women (1). Among the molecular subtypes of breast cancer, estrogen receptor (ER)-positive subtypes respond to anti-estrogen therapy (2), but have been observed to develop resistance (3). Triple-negative breast cancer, which does not express ER, progesterone receptor or human epidermal growth factor receptor 2 (HER2), is more aggressive and has a reduced number of treatment options (4). Anti-estrogens and trastuzumab are not effective for the treatment of triple-negative cancer, as cells do not express ER or HER2 (5); therefore chemotherapy is the only effective treatment option (6). Besides being expensive, radiotherapy and chemotherapy may cause serious side effects (7). Therefore, it is necessary to discover novel anticancer compounds that cause fewer adverse effects. Plants and other natural sources have provided $\sim 60 \%$ of anti-cancer agents currently in use (8); however, there are a number of traditionally used plants that remain to be scientifically validated. 
Mangifera zeylanica (family, Anacardiaceae) is a plant endemic to Sri Lanka, and is typically found in the intermediate and wet zone forests (9). It is commonly known as 'Etamba', and grows as a wild species that bears edible fruit. $M$. zeylanica has been used traditionally for cancer therapy in Sri Lanka. However, these claims have not been scientifically validated. Mangiferin is the only reported compound isolated from $M$. zeylanica (10). Therefore, the present study was conducted to evaluate the potential cytotoxic and apoptotic effects of $M$. zeylanica on breast and ovarian cancer cells and to identify phytochemical constituents in active fractions obtained from bioactivity-guided fractionation.

\section{Materials and methods}

Plant material, chemicals, cell lines and cell culture reagents. Approval was obtained from the Department of Wildlife Conservation, Government of Sri Lanka (Columbo, Sri Lanka) for collecting M. zeylanica bark for research. The bark (2.5 kg) was collected from Imaduwa (Galle, Sri Lanka) and the plant was identified by a botanist at Bandaranayke Memorial Ayurvedic Research Institute (BMARI; Nawinna, Maharagama, Sri Lanka). The voucher specimen (\#1221 A) was deposited at BMARI. All chemicals were purchased from Sigma-Aldrich (St. Louis, MO, USA) unless otherwise specified. Cell lines and $10 \%$ fetal bovine serum were acquired from the American Type Culture Collection (ATCC; Manassas, VA, USA).

Extraction and preparation of plant extract. Finely powdered dried bark $(2.5 \mathrm{~kg})$ was subjected to sequential extraction using hexane, chloroform, ethyl acetate and methanol (thrice with each solvent) by sonicating for $3 \mathrm{~h}$ at room temperature. All resulting extracts were filtered and evaporated using an R-3 rotary evaporator (BÜCHI Labortechnik AG, Flawil, Switzerland) under reduced pressure at $40^{\circ} \mathrm{C}$ to obtain crude extracts of hexane, chloroform, ethyl acetate and methanol. Stock solutions were prepared by dissolving in dimethyl sulfoxide (DMSO), and diluted to working solutions prior to use (the final DMSO concentration was $0.5 \% \mathrm{v} / \mathrm{v}$ ).

Preliminary phytochemical analysis, determination of total flavonoid and polyphenol content and free radical scavenging activity. Hexane extract of M. zeylanica was tested for the presence of polyphenols (11), flavonoids (12), lipids, sterols and saponins $(13,14)$ using previously described methods with minor modifications as required. Polyphenol content was expressed as gallic acid equivalent, and flavonoid content as quercetin equivalent, per $1 \mathrm{~g}$ of plant extract.

Free radical scavenging activity of the extract was investigated by 2,2-diphenyl-1-picrylhydrazyl (DPPH) assay (15) with minor modifications. Hexane extract $(0.5 \mathrm{ml})$ was added at various concentrations $(25,50,100,200$ and $400 \mu \mathrm{g} / \mathrm{ml})$ to $0.5 \mathrm{ml}$ of DPPH (Sigma-Aldrich) solution $(5.9 \mathrm{~g}$ in $100 \mathrm{ml}$ methanol) and incubated in the dark for $30 \mathrm{~min}$, followed by absorbance (A) reading at $517 \mathrm{~nm}$ (Synergy ${ }^{\mathrm{TM}}$ HT Multi-Mode Microplate Reader; Bio-Tek Instruments, Inc., Winooski, VT, USA). Percentage scavenging ability was calculated as half maximal effective concentration $\left(\mathrm{EC}_{50}\right)$ using the following equation: $\mathrm{EC}_{50}=\left(\mathrm{A}_{\text {control }}-\mathrm{A}_{\text {sample }}\right) / \mathrm{A}_{\text {control }} \times 100$. Ascorbic acid was utilized as the positive control.
Cell culture and cytotoxicity assay. MCF-7 human ER-positive breast cancer cells, MDA-MB-231 triple-negative breast cancer cells, SKOV-3 ovarian epithelial cancer cells and MCF-10A normal mammary epithelial cells were maintained in ATCC-recommended medium [MCF-7 cells, Dulbecco's modified Eagle's medium (DMEM; ATCC 30-2002); MDA-MB-231 cells: Leibovitz's L-15 medium (ATCC 30-2008); SKOV-3 cells, McCoy's 5A medium (ATCC 30-2007); and MCF-10A cells, DMEM (ATCC 30-2002)] with 10\% fetal bovine serum, insulin (Sigma-Aldrich; $0.01 \mathrm{mg} / \mathrm{ml}$ ), streptomycin (Sigma-Aldrich; $0.1 \mathrm{mg} / \mathrm{ml}$ ) and penicillin (Sigma-Aldrich; $100 \mathrm{U} / \mathrm{ml}$ ). All cells were cultured at $37^{\circ} \mathrm{C}$ in an atmosphere of $5 \% \mathrm{CO}_{2}$, with the exception of MDA-MB-231 cells, which were cultured without $\mathrm{CO}_{2}$. Cells were harvested by trypsinization and seeded into 96-well plates (product no. 3860-096; Iwaki Cell Biology, Iwaki, Japan) at a density of $5 \times 10^{3}$ cells/well. Following $24 \mathrm{~h}$ incubation, cells were treated with various doses $(25,50,100,200$ or $400 \mu \mathrm{g} / \mathrm{ml})$ of hexane, chloroform, ethyl acetate or methanol extracts, or mangiferin. The cytotoxic effect of the extracts was assessed by sulforhodamine B (SRB) assay following $24 \mathrm{~h}$ incubation (16). Briefly, cells were fixed using $50 \mu \mathrm{l}$ of ice-cold $50 \%$ trichloroacetic acid, incubated for $60 \mathrm{~min}$ at $4^{\circ} \mathrm{C}$, washed with tap water five times and stained using $0.4 \%$ SRB solution (100 $\mu \mathrm{l}$ stain/well). Plates were subsequently incubated at room temperature for $15 \mathrm{~min}$, SRB solution was decanted and unbound dye was removed by washing with $1 \%$ acetic acid five times, followed by air-drying. Unbuffered Tris-base solution ( $200 \mu 1 /$ well) was added to the wells to solubilize unbound SRB dye. The contents were mixed on an agitator for $1 \mathrm{~h}$ at room temperature. Absorbance was read at optical density $540 \mathrm{~nm}$ (Synergy ${ }^{\mathrm{TM}}$ HT Multi-Mode Microplate Reader) and percentage cell viability was calculated (mean of control group - mean of treated group / control group x 100\%). All experiments were performed in triplicate. Paclitaxel (Sigma-Aldrich) was utilized as the positive control. Negative controls received ATCC-recommended medium and DMSO.

Identification of active fractions of the M. zeylanica bark extract. The crude hexane extract, which was cytotoxic to cancer cells and less cytotoxic to normal cells, was subjected to a series of solvent-solvent partitions. It was initially partitioned between hexane and $\mathrm{MeOH} / \mathrm{H}_{2} \mathrm{O}(9: 1, \mathrm{v} / \mathrm{v})$ and subsequently, following separation of the hexane layer, the aqueous layer was diluted with water to a composition of $\mathrm{MeOH} / \mathrm{H}_{2} \mathrm{O}$ $(6: 4, v / v)$ and extracted with chloroform. The aqueous layer was subsequently concentrated under reduced pressure and partitioned between ethyl acetate and water. A total of four fractions, namely hexane-, chloroform-, ethyl acetate- and water-soluble fractions, were thus obtained. Cytotoxicity was contained in the chloroform-soluble fraction. The dried chloroform layer $(1.1 \mathrm{~g})$ was subjected to silica gel column chromatography (230-400 mesh; cat no. 177/03; Daihan Labtech India Pvt. Ltd., Delhi, India) and eluted with $100 \mathrm{ml}$ each of hexane-ethyl acetate $(8: 2,7: 3,6: 4,1: 1,4: 6,3: 7,2: 8,1: 9$, $\mathrm{v} / \mathrm{v})$, ethyl acetate-methanol $(1: 1, \mathrm{v} / \mathrm{v})$ and methanol. All the solvents for chromatography separations were purchased from Sigma-Aldrich. Active fractions identified by SRB assay were monitored by normal-phase thin-layer chromatography (TLC) using hexane-ethyl acetate $(1: 1, \mathrm{v} / \mathrm{v})$ as the mobile phase. As 
Table I. Primers used for reverse transcription-quantitative PCR and the PCR product size.

\begin{tabular}{lll}
\hline Gene & Forward primer, 5'-3' & Reverse primer, 5'-3' \\
\hline Bcl-2-associated X protein & TCCAGGATCGAGCAGGGCGAA & CGATGCGCTTGAGACACTCGCT \\
Tumor protein p53 & TCTGGCCCCTCCTCAGCATCTT & TTGGGCAGTGCTCGCTTAGTGC \\
Survivin & TGGCCGCTCCTCCCTCAGAAAA & GCTGCTGCCTCCAAAGAAAGCG \\
GAPDH & GGCATTGCCCTCAACGACCAC & ACATGACAAGGTGCGGCTCCCTA \\
\hline
\end{tabular}

PCR, polymerase chain reaction; Bcl, B-cell lymphoma 2; GAPDH, glyceraldehyde-3-phosphate dehydrogenase.

all cytotoxic fractions produced almost a clear spot during normal-phase TLC, all fractions were pooled and concentrated to give $\mathrm{T}_{1}$. $\mathrm{T}_{1}$ was monitored on reversed-phase TLC using methanol-water $(9.5: 0.5, \mathrm{v} / \mathrm{v})$ as the mobile phase, fractionated in a reversed-phase column $\left(\mathrm{C}_{18}\right)$, and eluted with $10 \mathrm{ml}$ each of methanol-water $(7: 3,8: 3,9: 3, \mathrm{v} / \mathrm{v})$ and methanol. Fractions identified as most cytotoxic by SRB assay were monitored by reversed-phase TLC using methanol-water (9:1, v/v) as the mobile phase. Following observation of the behaviour of these fractions in reversed phase-TLC, $500 \mu \mathrm{l}$ from each active fraction was pooled to give the final fraction $\left(\mathrm{M}_{1}\right)$ and its cytotoxicity to cancer cells and normal mammary epithelial cells was assessed.

Evaluation of apoptotic effects. The potential apoptotic effects of the hexane extract were assessed by investigating its effect on caspase- 3 and -7 activity, morphological changes and DNA fragmentation. The effect on caspase- 3 and -7 activity was determined in the three cancer cell lines. Cells were treated with the hexane extract for $4 \mathrm{~h}(25,50,100,150$ and $200 \mu \mathrm{g} / \mathrm{ml})$ or $24 \mathrm{~h}(5,10,25,50$ and $100 \mu \mathrm{g} / \mathrm{ml})$. Caspase activity was assessed using ApoTox-Glo ${ }^{\mathrm{TM}}$ triplex assay according to the manufacturer's protocol (Promega Corporation, Madison, WI, USA) and compared with untreated controls.

The three cancer cell lines $\left(5 \times 10^{5}\right.$ cells $\left./ \mathrm{ml}\right)$ were treated with 200 and $400 \mu \mathrm{g} / \mathrm{ml}$ of the hexane extract for $24 \mathrm{~h}$ and harvested by trypsinization and centrifugation. The resulting cell pellets were subsequently incubated for $1 \mathrm{~h}$ at $55^{\circ} \mathrm{C}$ in freshly prepared lysis buffer $(5 \mathrm{mM}$ Tris- $\mathrm{HCl}, \mathrm{pH} 8 ; 1 \mathrm{M}$ $\mathrm{NaCl}$ and $5 \mathrm{mM}$ ethylenediaminetetraacetic acid, $\mathrm{pH} 8$; $0.5 \%$ sodium dodecyl sulfate and proteinase $\mathrm{K} ; 200 \mu \mathrm{g} / \mathrm{ml}$ ). Following incubation with RNaseA $(200 \mu \mathrm{g} / \mathrm{ml})$ for $2 \mathrm{~h}$ at $50^{\circ} \mathrm{C}$, DNA was extracted using phenol-chloroform-isoamyl alcohol. Extracted DNA was visualised under ultraviolet light to assess the effect on DNA fragmentation (Quantum-ST4 1100/20 M; Fisher Biotec Pty Ltd., Wembley, Australia) following electrophoresis on a $2.0 \%$ agarose gel stained with ethidium bromide (EB).

Cell morphology was assessed by examining acridine orange (AO)/EB-stained (17) treated cells. Cells at 70-80\% confluence were harvested by trypsinization, seeded into 24 -well plates (Iwaki Cell Biology) on cover slips $\left(5 \times 10^{4}\right.$ cells/well) and incubated for $24 \mathrm{~h}$ in a humidified atmosphere at $37^{\circ} \mathrm{C}$ in $5 \%$ $\mathrm{CO}_{2}$. Cells were subsequently treated with $25,50,100,200$ and $400 \mu \mathrm{g} / \mathrm{ml}$ hexane extract, incubated for $24 \mathrm{~h}$, rinsed with cold phosphate-buffered saline and fixed with $4 \%$ formaldehyde at room temperature. AO/EB solution (10-20 $\mu \mathrm{l})$ was added to
Table II. Qualitative phytochemical screening of the hexane extract of Mangifera zeylanica.

Phytochemical Presence/absence

\section{Steroids}

Flavonoids $+++$

Phenolic compounds

Tannins

Reducing sugars

Saponins

++++, appreciable amount; +, low amount; -, not detectable.

each well and cells were observed under a fluorescence microscope (BX51 TRF; Olympus Corporation, Tokyo, Japan).

RNA isolation and reverse transcriptase quantitative polymerase chain reaction $(R T-q P C R)$. The three cancer cell lines (200,000 cells/ml) were cultured in cell culture flasks, treated with the hexane extract at 100 or $150 \mu \mathrm{g} / \mathrm{ml}$ for $4 \mathrm{~h}$, and 50 or $75 \mu \mathrm{g} / \mathrm{ml}$ for $24 \mathrm{~h}$. Following treatment, cells were harvested and total RNA was extracted with TRIzol ${ }^{\circledR}$ Reagent (Invitrogen; Thermo Fisher Scientific, Inc., Carlsbad, CA, USA) according to the manufacturer's protocol. Total extracted RNA $(2 \mu \mathrm{g})$ and $50 \mathrm{ng}$ of random primers (Integrated DNA Technologies, Coralville, USA) were mixed in a PCR tube $(0.2 \mathrm{ml})$ and the total volume was made up to $13.5 \mu \mathrm{l}$ with diethylpyrocarbonate (DEPC)-treated ultrapure water for reverse transcription. The resulting RNA-random primer mixture was denatured at $70^{\circ} \mathrm{C}$ for $5 \mathrm{~min}$ and subsequently quenched on ice for 2 min to prevent formation of secondary structures. Complementary (c)DNA was synthesized by adding $5 \mu \mathrm{l} 5 \mathrm{X}$ buffer, $5 \mu \mathrm{l} 10 \mathrm{mM}$ deoxynucleotide mixture (deoxyadenosine triphosphate, deoxyguanosine triphosphate, deoxycytidine triphosphate and deoxythymidine triphosphate), 25 units of RNasin and 200 units of Moloney murine leukemia virus reverse transcriptase (all Thermo Fisher Scientific, Inc.), and the reaction mixture $(25 \mu \mathrm{l})$ was incubated at $37^{\circ} \mathrm{C}$ for 60 min by using a thermal cycler. RT-qPCR was performed in Stratagene Mx3000P using the MESA Green qPCR Master Mix Plus for SYBR Assay (Eurogentec, Seraing, Liège, Belgium) with the primers listed in Table I (except for p53 in SKOV-3 cancer cells, which are p53-null; Integrated DNA Technologies). Glyceraldehyde-3-phosphate dehydrogenase (GAPDH) was utilized as the housekeeping gene. The reaction 
Table III. $\mathrm{IC}_{50}$ values of solvent extracts of Mangifera zeylanica, mangiferin, paclitaxel and $\mathrm{M}_{1}$ fraction on MCF-7 and MDA-MB-231 breast cancer cell lines, SKOV-3 ovarian cancer cell line and MCF-10A normal mammary epithelial cells.

\begin{tabular}{lcccc}
\hline & \multicolumn{3}{c}{ IC $_{50}$ value $^{\mathrm{a}}$} \\
\cline { 2 - 5 } Extract/compound & MCF-7 cells $^{\mathrm{b}}$ & MDA-MB-231 cells & SKOV-3 cells $^{\mathrm{b}}$ & MCF-10A cells $^{\mathrm{b}}$ \\
\hline Hexane extract, $\mu \mathrm{g} / \mathrm{ml}$ & $87.64 \pm 0.37$ & $116.5 \pm 0.32$ & $86.6 \pm 0.48$ & $217.2 \pm 0.33$ \\
Chloroform extract, $\mu \mathrm{g} / \mathrm{ml}$ & $422.9 \pm 0.40$ & $280.1 \pm 3.44$ & $506.5 \pm 1.17$ & $92.86 \pm 0.53$ \\
Ethyl acetate extract, $\mu \mathrm{g} / \mathrm{ml}$ & $>1000$ & $>1000$ & $>1000$ & $>1000$ \\
Methanol extract, $\mu \mathrm{g} / \mathrm{ml}$ & $>1000$ & $>1000$ & $>1000$ & $>1000$ \\
Mangiferin, $\mu \mathrm{g} / \mathrm{ml}$ & $>1000$ & $>1000$ & $>1000$ & Not assessed \\
Paclitaxel, $\mu \mathrm{M}$ & $0.9959 \pm 0.04$ & $1.129 \pm 0.08$ & $0.7807 \pm 0.03$ & Not assessed \\
$\mathrm{M}_{1}$ fraction, $\mu \mathrm{g} / \mathrm{ml}$ & $28.05 \pm 0.84$ & $15.42 \pm 0.41$ & $38.66 \pm 0.42$ & $114.6 \pm 0.32$ \\
\hline
\end{tabular}

${ }^{\mathrm{a}}$ Mean \pm standard deviation of three independent experiments; ${ }^{\mathrm{b}}$ cancer cells; ${ }^{\mathrm{c}}$ normal cells. $\mathrm{IC}_{50}$, half maximal inhibitory concentration.

was performed in a total volume of $25 \mu \mathrm{l}$, containing $2 \mu \mathrm{l} \mathrm{cDNA}$ sample, $0.5 \mu \mathrm{l}$ of each primer $(0.5 \mu \mathrm{M}), 12.5 \mu \mathrm{l}$ SYBR Green reaction mix and DEPC-treated ultrapure water $(9.5 \mu \mathrm{l})$. PCR amplification was performed in duplicate wells. The cycling conditions were as follows: Denaturation step $\left(95^{\circ} \mathrm{C}\right.$ for $10 \mathrm{~min}$ ), and 40 cycles of three-step amplification (denaturation, $95^{\circ} \mathrm{C}$ for $30 \mathrm{sec}$; annealing, $56^{\circ} \mathrm{C}$ for $1 \mathrm{~min}$; and extension, $72^{\circ} \mathrm{C}$ for $1 \mathrm{~min}$ ). In addition, the real-time reaction of the products was examined by analyzing the melting point following each reaction. The formula $\Delta \mathrm{Cq}=\mathrm{Cq}_{\text {target gene }}-\mathrm{Cq}_{\mathrm{GAPDH}}$ was used to determine the $\Delta \mathrm{Cq}$ values. Following this initial calculation, $\Delta \Delta \mathrm{Cq}$ values were calculated using the formula $\Delta \Delta \mathrm{Cq}=\Delta \mathrm{Cq}_{\text {treated }}-\Delta \mathrm{Cq}_{\text {untreated }}$. Expression of the gene of interest in the treated cells was measured relative to that of the untreated control cells. Results were quantified using the formula $2^{-\Delta \Delta \mathrm{Cq}}(18)$.

Gas chromatography-mass spectrometry (GC-MS) analysis of crude hexane extract and fraction $M_{l}$. Agilent GC-MS (7890A GC, 5975C MS; Agilent Technologies, Inc., Santa Clara, CA, USA) was used for chromatographic analysis. An ionization voltage of $70 \mathrm{eV}$, injector and detector temperatures of $260^{\circ} \mathrm{C}$ and $320^{\circ} \mathrm{C}$, respectively, and J\&W DB-5 MS capillary columns (30 m length, $250 \mu \mathrm{m}$ internal diameter and $0.25 \mu \mathrm{m}$ thickness) were used. The oven temperature was initiated at $110^{\circ} \mathrm{C}$ (isothermal for $5 \mathrm{~min}$ ), increased to $280^{\circ} \mathrm{C}$ at $20^{\circ} \mathrm{C} / \mathrm{min}$ (isothermal for $1 \mathrm{~min}$ ) and increased again to $320^{\circ} \mathrm{C}$ at $20^{\circ} \mathrm{C} / \mathrm{min}$ (isothermal for $5 \mathrm{~min}$ ). Helium was the carrier gas and this was used at a flow rate of $1.5 \mathrm{ml} / \mathrm{min}$, with an injector volume of $1 \mu \mathrm{l}$ with splitless mode. The hexane extract and $\mathrm{M}_{1}$ fraction were dissolved in hexane $(1 \mathrm{mg} / \mathrm{ml})$, filtered through $0.2 \mu \mathrm{m}$ syringe filters (Sigma-Aldrich) and injected into the GC-MS. The mass spectrum of each compound was identified by comparison to the National Institute of Standards and Technology library (http://www.nist.gov/).

Statistical analyses. GraphPad Prism 5 (GraphPad Software, Inc., La Jolla, CA, USA) was used for statistical analysis. Results are expressed as the mean \pm standard deviation of three independent experiments. One way analysis of variance
Table IV. Major lipophilic compounds of the hexane extract and $\mathrm{M}_{1}$ fraction obtained from bioactivity-guided fractionation of the hexane extract of Mangifera zeylanica, identified by gas chromatography-mass spectrometry analysis.

A, Hexane extract

\begin{tabular}{|c|c|c|}
\hline $\begin{array}{l}\text { Retention } \\
\text { time, min }\end{array}$ & $\begin{array}{c}\text { Area, } \\
\%\end{array}$ & Compound name \\
\hline 6.389 & 0.42 & 3-methyl heptadecane \\
\hline 11.454 & 5.64 & Hexacosane \\
\hline 13.650 & 0.42 & Campesterol \\
\hline 13.816 & 0.47 & Stigmasterol \\
\hline 14.222 & 2.90 & $\beta$-sitosterol \\
\hline 14.224 & 2.90 & $\gamma$-sitosterol \\
\hline 14.394 & 1.16 & Lanosterol \\
\hline 14.892 & 6.76 & $\begin{array}{l}\text { 9,19-cyclolanost-24-en-3-ol } \\
\text { (cycloartenol) }\end{array}$ \\
\hline 14.962 & 2.15 & Lanosterol \\
\hline 15.026 & 1.21 & $\beta$-amyrin \\
\hline 16.262 & 6.61 & $\begin{array}{l}\text { 4,4-dimethyl-2-nonadecyl-5H-1,3- } \\
\text { oxazole }\end{array}$ \\
\hline
\end{tabular}

$\mathrm{B}, \mathrm{M}_{1}$ fraction

\begin{tabular}{rrl}
\hline $\begin{array}{l}\text { Retention } \\
\text { time, min }\end{array}$ & \multicolumn{1}{c}{$\begin{array}{c}\text { Area, } \\
\%\end{array}$} & \multicolumn{1}{c}{ Compound name } \\
\hline 3.845 & 6.25 & Unknown \\
4.315 & 1.36 & Unknown \\
4.754 & 19.99 & Unknown \\
5.883 & 3.49 & Oleana-2,12-dien-29-oic acid \\
5.932 & 4.27 & Unknown \\
6.942 & 1.27 & Unknown \\
14.283 & 10.12 & Unknown \\
22.754 & 1.48 & 2-ethylacridine \\
31.593 & 1.25 & 2-oxo-n-propyl-2- \\
& & (veratrylidenehydrazino) acetamide
\end{tabular}


A
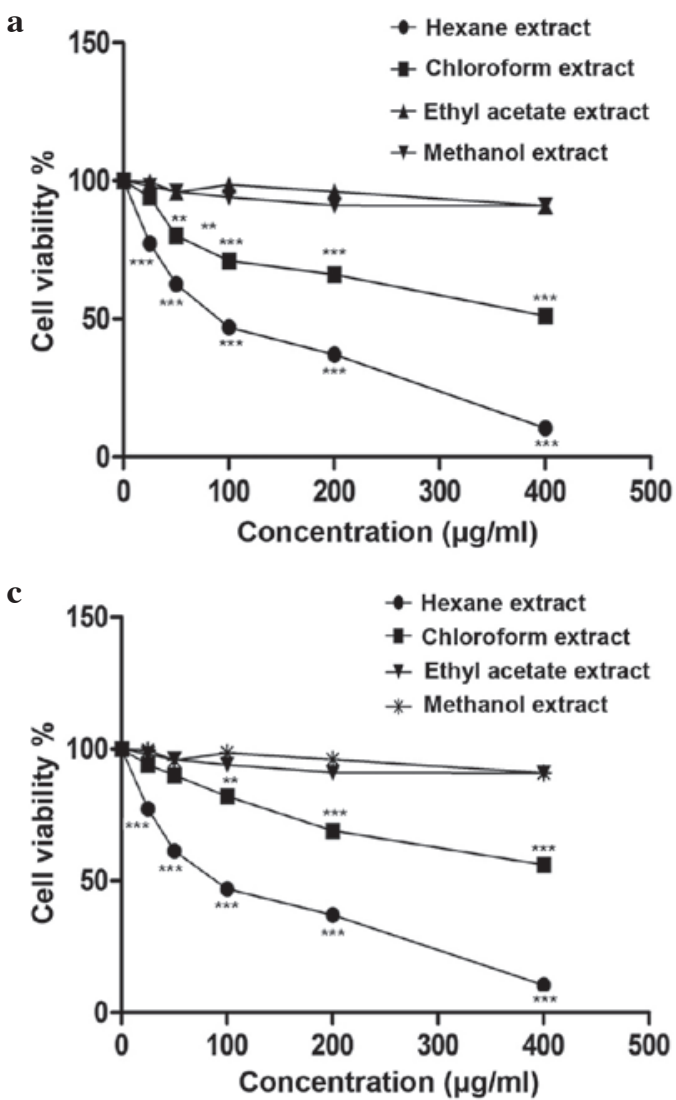

B

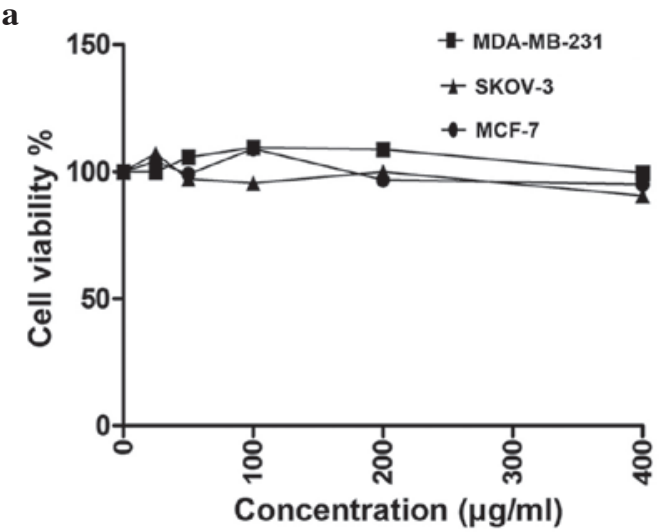

c

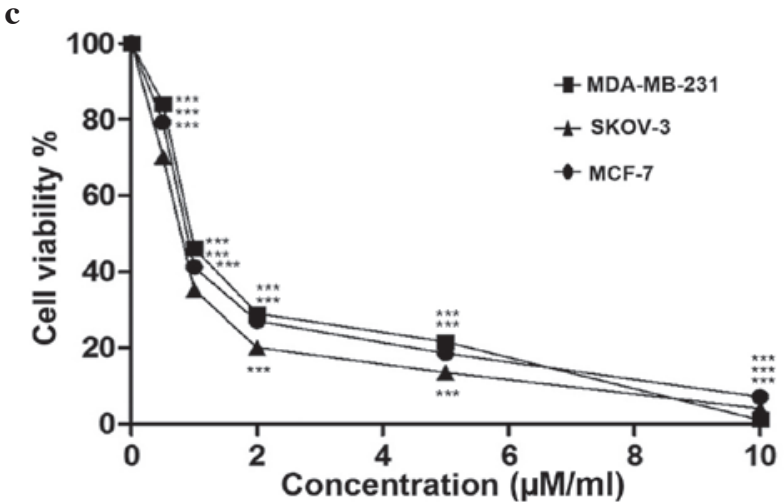

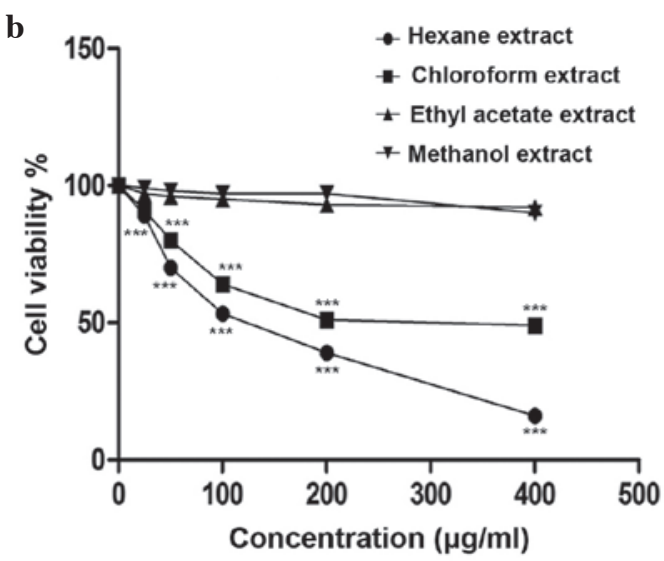

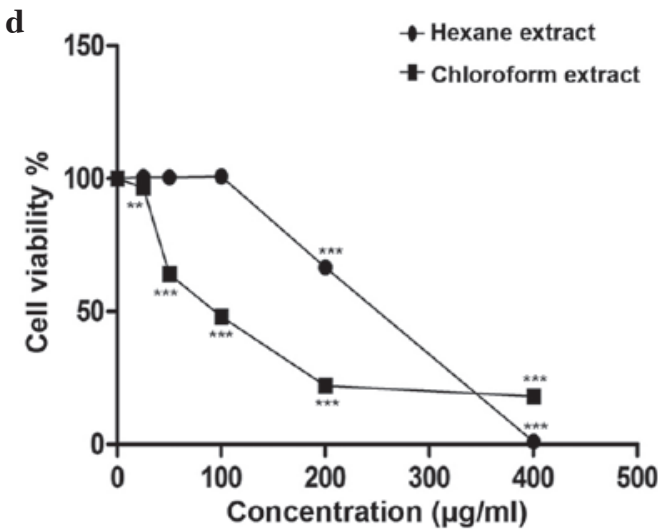

b

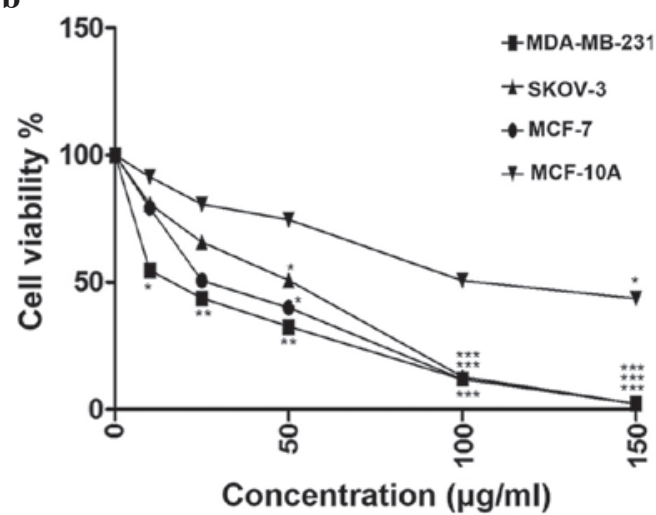

Figure 1. (A) Cytotoxic activity of the solvent extracts of Mangifera zeylanica: Cytotoxic activity of four solvent (hexane, chloroform, ethyl acetate and methanol) extracts of M. zeylanica on (a) MCF-7 and (b) MDA-MB-231 breast cancer cell lines and (c) the SKOV-3 ovarian cancer cell line; and (d) cytotoxic activity of hexane and chloroform extracts of $M$. zeylanica on the MCF-10A normal mammary epithelial cell line. (B) Cytotoxic activity of (a) mangiferin, (b) $\mathrm{M}_{1}$ fraction of $M$. zeylanica and (c) paclitaxel on cancer cell lines (MCF-7, MDA-MD-231 and SKOV-3) and a normal mammary epithelial cell line (MCF-10A). ${ }^{*} \mathrm{P}<0.05,{ }^{* *} \mathrm{P}<0.01$ and ${ }^{* * *} \mathrm{P}<0.001$ vs. control. Data are presented as the mean values from three independent experiments. 

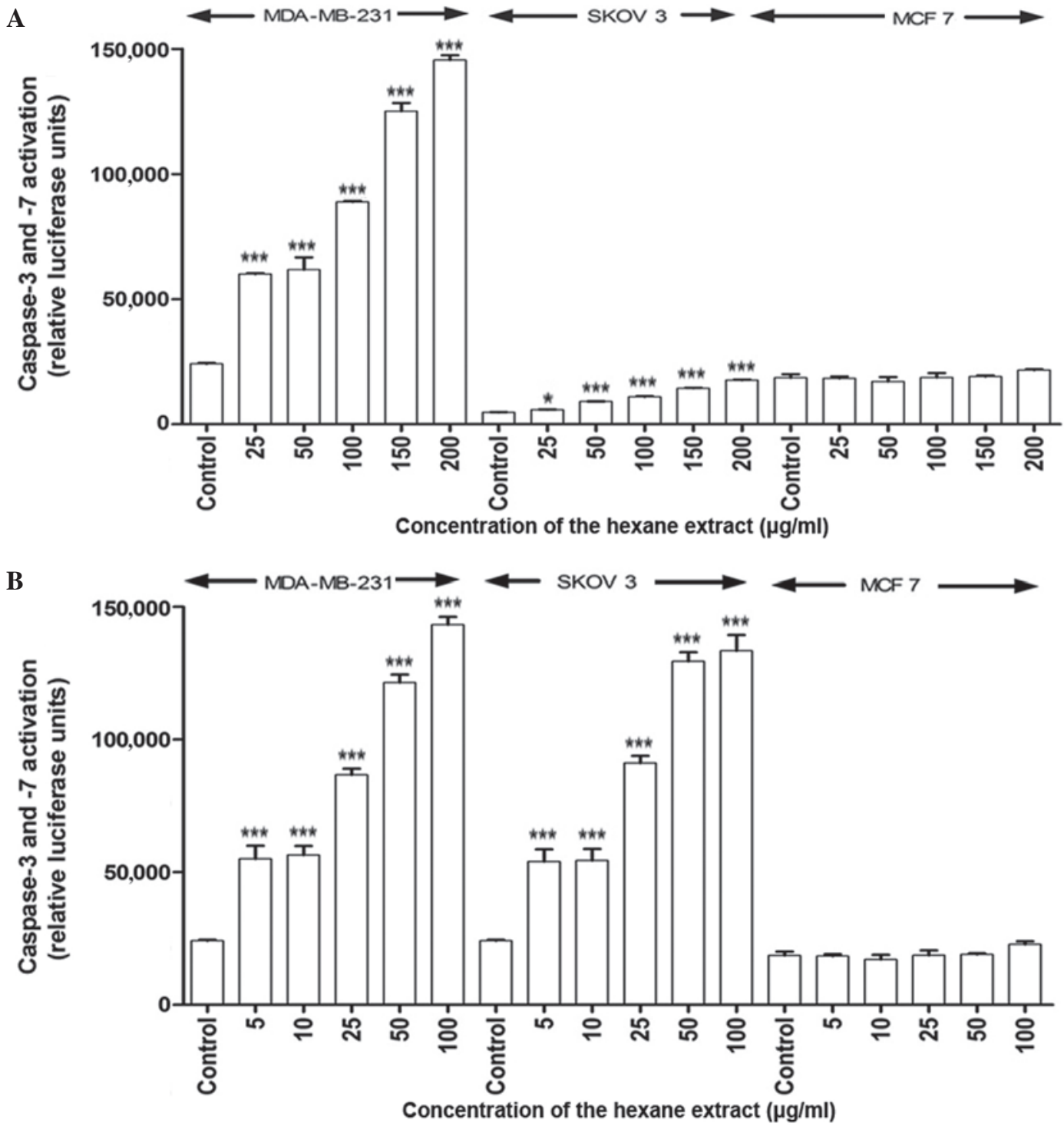

Figure 2. Caspase activation in cancer cell lines in response to the hexane extract of Mangifera zeylanica. Activation of caspases in MDA-MB-231 and SKOV-3 cells (caspase-3 and -7) and MCF-7 cells (caspase-7) at (A) $4 \mathrm{~h}$ and (B) $24 \mathrm{~h}$ after treatment with the hexane extract. ${ }^{*} \mathrm{P}<0.05$ and ${ }^{* * * *} \mathrm{P}<0.001 \mathrm{compared}$ with the control. Data are presented as the mean \pm standard deviation.

with Dunnett's post hoc test was used to compare groups, and $\mathrm{P}<0.05$ was considered to indicate a statistically significant difference.

\section{Results}

Phytochemical investigation, extract yields, and total polyphenol and flavonoid content in hexane extract of M. zeylanica bark. From $2.5 \mathrm{~kg}$ of powdered bark material, $5.20,5.89,13.42$ and $138.92 \mathrm{~g}$ of hexane, chloroform, ethyl acetate and methanol extracts were obtained, corresponding to yields of $0.208,0.236,0.5368$ and $5.568 \%$, respectively. Qualitative phytochemical investigation revealed that the hexane extract contained steroids, flavonoids, phenolic compounds, tannins and reducing sugars, while saponins were not detected (Table II). The total polyphenolic and flavonoid content in the n-hexane extract was $113.2 \mathrm{mg}$ gallic acid equivalent and $30.4 \mathrm{mg}$ quercetin equivalent, respectively, per $1 \mathrm{~g}$ of dried hexane extract.
Varying levels of cytotoxicity of extracts and $M_{1}$ fraction are observed in distinct cell lines. $\mathrm{IC}_{50}$ values of the four solvent extracts of $M$. zeylanica bark, fraction $\mathrm{M}_{1}$, mangiferin and paclitaxel are provided in Table III. Of the four solvent extracts, only the hexane and chloroform extracts demonstrated significant cytotoxicity to all three cancer cell lines in a dose-dependent manner, following $24 \mathrm{~h}$ of incubation [MCF-7 (87.64 $\pm 0.37 \mu \mathrm{g} / \mathrm{ml}$ hexane, $\mathrm{P}<0.0001$; $422.9 \pm 0.40 \mu \mathrm{g} / \mathrm{ml}$ chloroform, $\mathrm{P}<0.0001)$; MDA-MB-231 $(116.5 \pm 0.32 \mu \mathrm{g} / \mathrm{ml}$ hexane, $\mathrm{P}<0.0001 ; 280.1 \pm 3.44 \mu \mathrm{g} / \mathrm{ml}$ chloroform, $\mathrm{P}<0.0001)$; SKOV-3 $(86.6 \pm 0.48 \mu \mathrm{g} / \mathrm{ml}$ hexane, $\mathrm{P}<0.0001 ; 506.5 \pm 1.17 \mu \mathrm{g} / \mathrm{ml}$ chloroform, $\mathrm{P}<0.0001)$ and MCF-10A cells $(217.2 \pm 0.33 \mu \mathrm{g} / \mathrm{ml}$ hexane, $\mathrm{P}<0.0001$; $92.86 \pm 0.53 \mu \mathrm{g} / \mathrm{ml}$ chloroform, $\mathrm{P}<0.0001)]$. The hexane extract was highly cytotoxic to the three cancer cell lines and less cytotoxic to normal mammary epithelial cells. By contrast, the chloroform extract was less cytotoxic to the cancer cell lines and highly cytotoxic to normal cells. Mangiferin was not cytotoxic to the cancer cell lines 
A
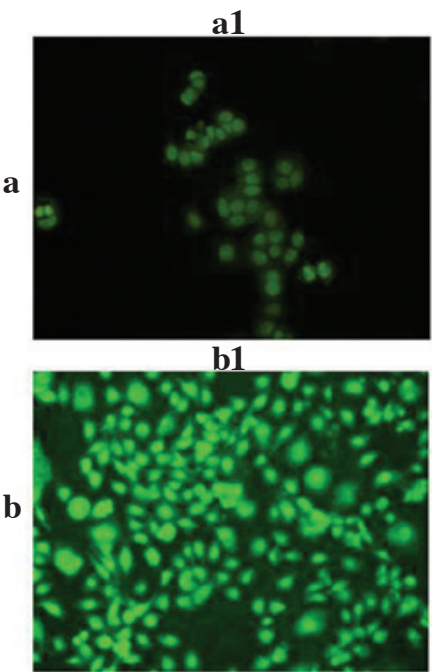

c1

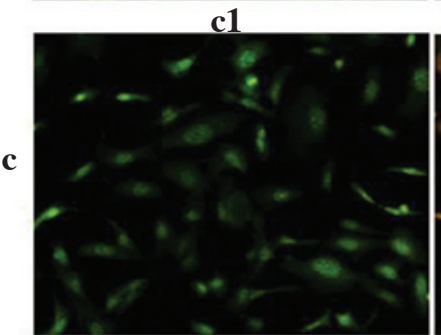

Control a2

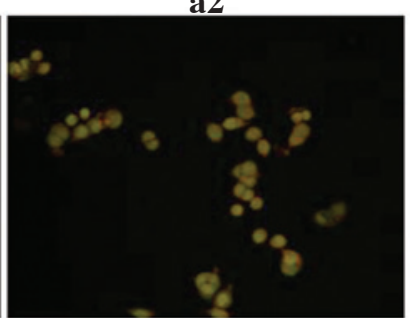

b2

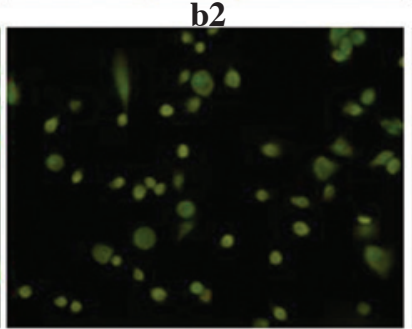

c2

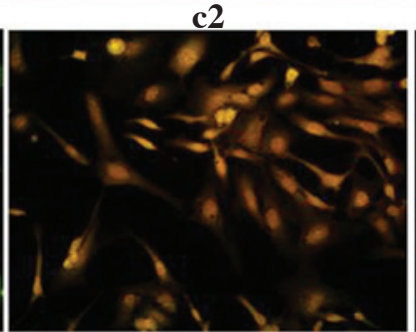

$50 \mu \mathrm{g} / \mathrm{ml}$ a3

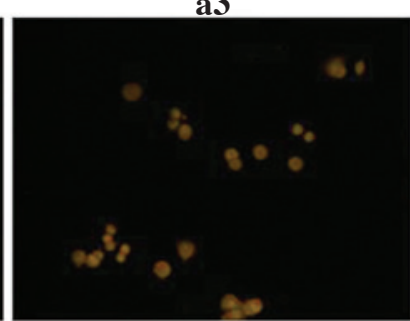

b3

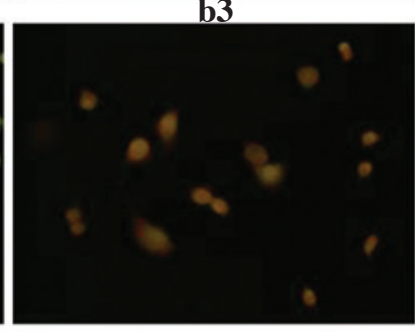

c3

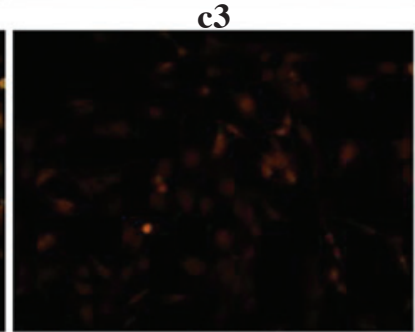

$200 \mu \mathrm{g} / \mathrm{ml}$

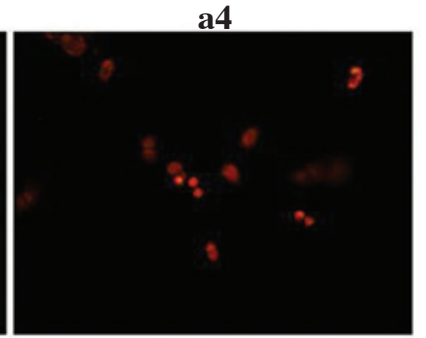

b4

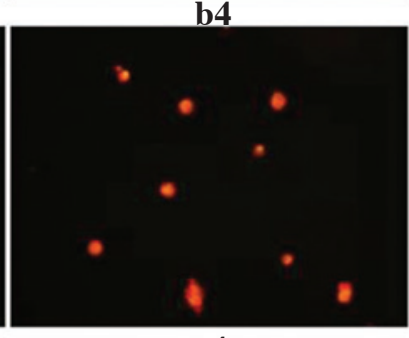

c4

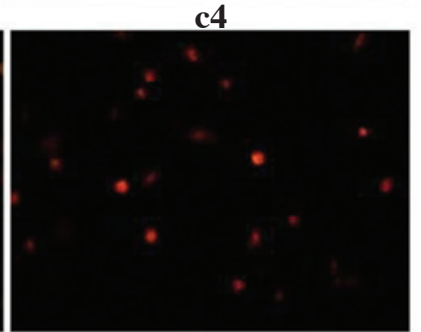

$400 \mu \mathrm{g} / \mathrm{ml}$

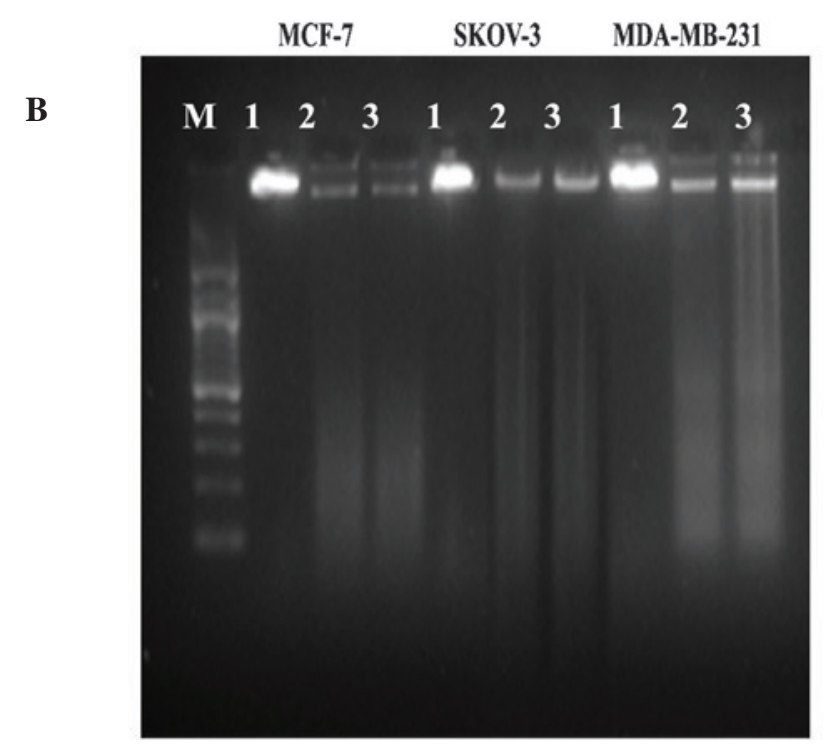

Figure 3. Effect of the hexane extract of Mangifera zeylanica on morphological changes and DNA fragmentation. (A) Morphological observations following acridine orange/ethidium bromide staining in three cancer cell lines treated with the hexane extract for 24 h: (a) MCF-7 cells, (b) MDA-MB-231 cells, and (c) SKOV-3 cells. (a1-c1) control cells; (a2-c2) cells treated with $50 \mu \mathrm{g} / \mathrm{ml}$; (a3-c3) cells treated with 200 $\mu \mathrm{g} / \mathrm{ml}$; and (a4-c4) cells treated with 400 $\mu \mathrm{g} / \mathrm{ml}$ of the hexane extract. (B) DNA fragmentation visualized by $2 \%$ agarose gel electrophoresis: M, 100 bp DNA ladder; 1 , untreated control; $2,400 \mu \mathrm{g} / \mathrm{ml}$ hexane extract; $3,600 \mu \mathrm{g} / \mathrm{ml}$ hexane extract.

investigated in the present study. Fraction $\mathrm{M}_{1}$ was strongly cytotoxic to the three cancer cell lines and less cytotoxic to normal cells (Fig. 1A and B). Among the cancer cell lines studied, the highest cytotoxic response was observed in the MDA-MB-231 triple-negative cell line $(15.42 \pm 0.41 \mu \mathrm{g} / \mathrm{ml})$.

Apoptosis is induced by the hexane extract of $M$. zeylanica bark. In response to treatment with the hexane extract, caspase-3 and -7 activity significantly increased in MDA-MB-231 and SKOV-3 cells in a time- and dose-dependent manner $(\mathrm{P}<0.001)$ compared with the positive control (ascorbic acid; $\mathrm{EC}_{50}=4.2 \mu \mathrm{g} / \mathrm{ml}$ ); however, caspase-7 was not activated in MCF-7 cells at 4 or 24 h post-incubation (Fig. 2). The $\mathrm{EC}_{50}$ values obtained for the hexane extract indicate that it has free radical scavenging activity, although its activity is lower than that of ascorbic acid (values higher than the positive control have a lower activity). AO/EB staining (Fig. 3A) revealed primary morphological evidence of apoptosis (including 
A a

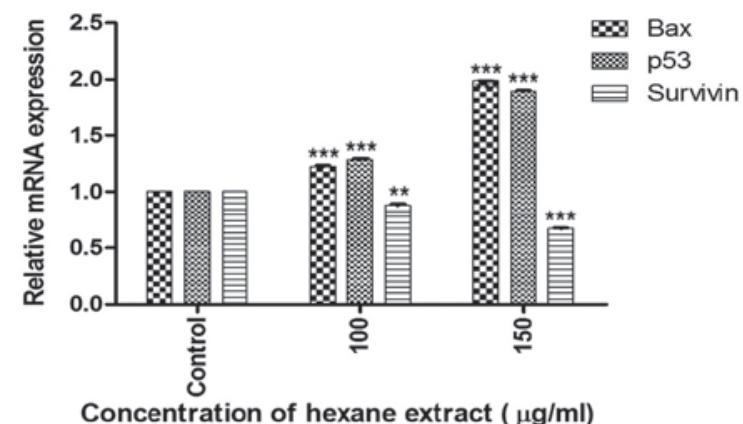

Concentration of hexane extract $(\mu \mathrm{g} / \mathrm{ml})$

B $\mathbf{a}$

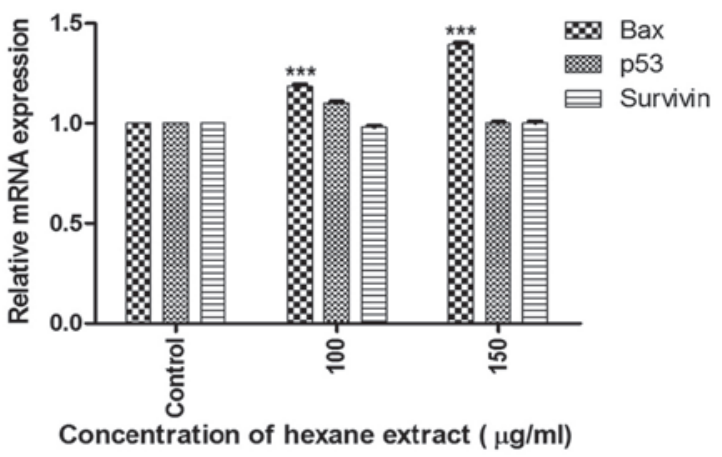

C a

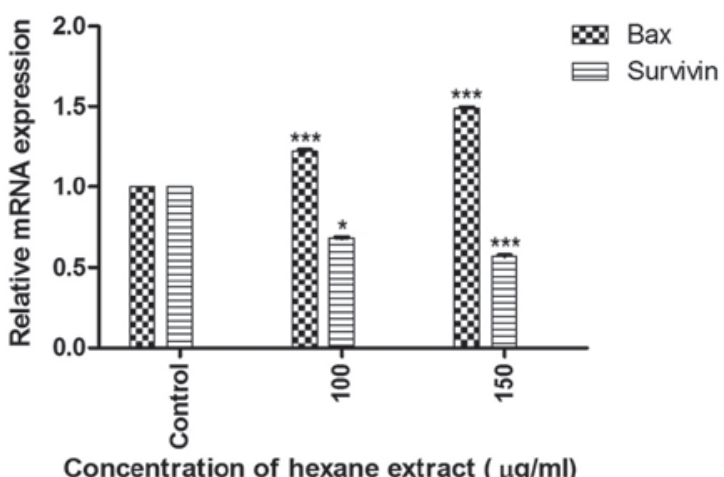

b

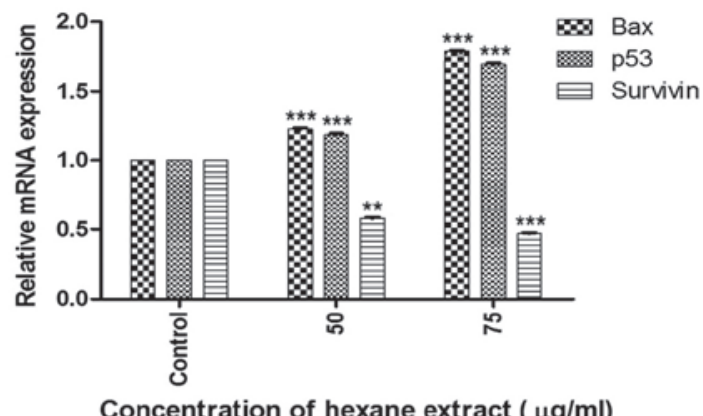

Concentration of hexane extract $(\mu \mathrm{g} / \mathrm{ml})$

b

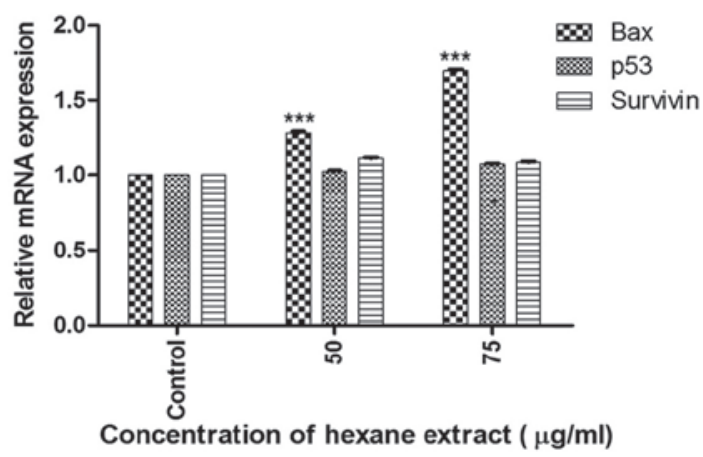

b

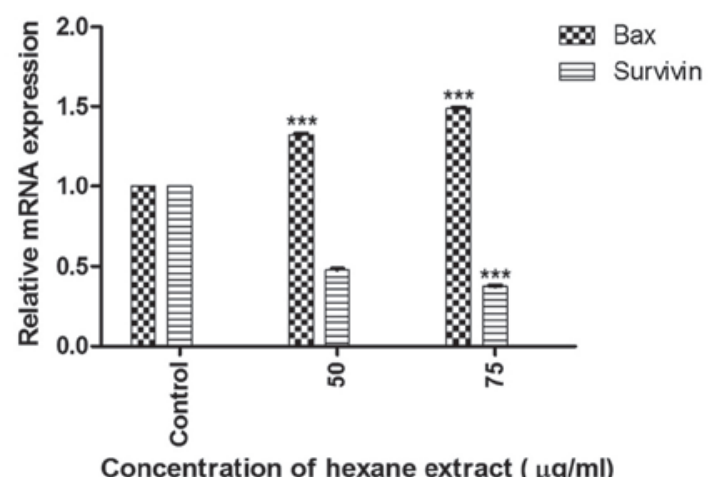

Figure 4. Effect of the hexane extract of Mangifera zeylanica on the expression of apoptosis-associated genes. Relative expression of p53, Bax and Survivin mRNA genes in (A) MCF-7, (B) MDA-MB-231 and (C) SKOV-3 cancer cells treated with various concentrations of the hexane extract for (a) $4 \mathrm{~h}$ or (b) $24 \mathrm{~h}$. p53 was not studied in SKOV-3 cells as they do not express it. ${ }^{*} \mathrm{P}<0.05,{ }^{* *} \mathrm{P}<0.01$ and ${ }^{* * * *} \mathrm{P}<0.001$ compared with the control (untreated cells). Data are presented as the mean \pm standard deviation. $\mathrm{p} 53$, tumor protein $\mathrm{p} 53$; Bax, B-cell lymphoma 2-associated $\mathrm{X}$ protein.

chromatin condensation, nuclear fragmentation and changes in the size and shape of cells) in the three cancer cell lines at $24 \mathrm{~h}$ post-incubation. DNA fragmentation, a characteristic of late apoptosis, was observed in the three cancer cell lines exposed to the hexane extract for $24 \mathrm{~h}$, with no such evidence observed in control cells (Fig. 3B).

RT-qPCR analysis of p53, Bcl-2-associated X protein (Bax) and survivin genes reveals differential expression of various tumor-associated factors. The relative mRNA expression of the genes investigated in the three cancer cell lines is shown in Fig. 4. RT-qPCR evaluation of cells treated with the hexane extract of M. zeylanica bark demonstrated that this extract significantly increased the expression of p53 and Bax mRNA, and decreased the expression of survivin mRNA in MCF-7 cells. In MDA-MB-231 cells, Bax expression was increased; however, p53 and survivin expression were not affected. In SKOV-3 cells, upregulation of Bax and downregulation of survivin was observed.
Hexane extract of M. zeylanica bark demonstrates free radical scavenging activity. The DPPH free radical scavenging assay of the hexane extract gave an $\mathrm{EC}_{50}$ value of $33.1 \mu \mathrm{g} / \mathrm{ml}$.

Phytochemical analysis by GC-MS identifies 11 lipophilic compounds. GC-MS analysis of the hexane extract of M.zeylanica bark tentatively identified 11 lipophilic compounds. The hexane extract was rich in sterols and long-chain hydrocarbons. Compositional analysis of the $\mathrm{M}_{1}$ fraction by GC-MS revealed that it contained 7 unknown compounds along with a small number of known compounds (Table IV).

\section{Discussion}

Of the four organic extracts of $M$. zeylanica bark, the percentage yield was lowest for the hexane extract. However, the hexane extract was selectively cytotoxic to the cancer cells investigated in the present study and contained secondary metabolites, including flavonoids, tannins, steroids, reducing 
sugars and phenolic compounds, while saponins were absent. The polyphenol content of the hexane extract was greater than the flavonoid content.

The cytotoxicity of the hexane extract to ER-positive (MCF-7) and triple-negative breast cancer cells (MDA-MB-231), and to ovarian epithelial cells (SKOV-3) was dose-dependent, and this extract demonstrated reduced cytotoxicity to normal mammary epithelial cells. By contrast, the chloroform extract demonstrated reduced cytotoxicity in the cancer cells and increased cytotoxicity in the normal cells investigated in the present study. The $\mathrm{M}_{1}$ fraction, obtained from fractionation of the hexane extract, additionally demonstrated high levels of cytotoxicity in the three cancer cell lines and reduced cytotoxicity in normal mammary epithelial cells. Notably, the highest cytotoxicity was exerted on triple-negative cells. Mangiferin was not observed to exert cytotoxic effects on any of the cancer cell lines investigated in the present study. García-Rivera et al (19) failed to identify any significant cytotoxicity of mangiferin in MDA-MB-231 cells. Thus, compound(s) other than mangiferin in M. zeylanica appear to mediate the cytotoxic and apoptotic effects observed in the present study.

The processes of homeostasis of organs and tissues depends upon the vital role of apoptosis, the dysregulation of which may be observed in cancer $(20,21)$. Apoptosis involves the sequential activation of a cascade of proteases, known as caspases. There are two classes of caspase, initiators and effectors, and the latter class includes caspase-3 and -7 (22). The extrinsic and intrinsic pathways of apoptosis merge to form a common pathway, which is mediated by these effector caspases (23).

In the present study, characteristic features of apoptosis, including activation of caspase-3 and -7 (except in MCF-7 cells), nuclear fragmentation and chromatin condensation were clearly observed in the three cancer cell lines in response to treatment with the hexane extract of $M$. zeylanica bark. Activation of caspase-7 was not observed in MCF-7 cells, and these cells do not express caspase-3. Thus, it is possible that the hexane extract caused caspase-independent apoptosis in MCF-7 cells through the intrinsic pathway, potentially via activation of apoptosis-inducing factor or endonuclease $\mathrm{G}$, which are responsible for DNA fragmentation (24). Triple-negative breast cancer cells and ovarian epithelial cancer cells demonstrated typical activation of caspase- 3 and -7 following exposure to the hexane extract. As the presence of caspase- 3 and -7 alone is not able to signify whether the intrinsic or extrinsic pathway has been activated, additional components require investigation in order to ascertain the pathways activated.

Bax and p53 genes have significant roles in apoptosis; increased expression of Bax is known to induce apoptosis (25), while p53, in addition to mediating apoptosis, regulates the antiapoptotic gene survivin (26). In the present study, the upregulation of Bax and p53, with concomitant downregulation of survivin, observed in MCF-7 breast cancer cells in response to the hexane extract suggested that apoptosis in these cells may be mediated via the intrinsic pathway. Triple-negative breast cancer cells, which carry a mutant p53, demonstrated upregulation of Bax, while p53 and survivin expression was not altered in these cells following treatment with the hexane extract; this suggested that a p53-independent pathway may mediate apoptosis in these cells. In the ovarian epithelial cancer cells, which are p53 null, proapoptotic Bax was upregulated and antiapoptotic survivin was downregulated. It is likely that a p53-independent pathway, such as the mitochondria-dependent 'intrinsic' cytochrome pathway, is involved in the mediation of apoptosis in these cells (27). The effect of the hexane extract on the activation of caspases and on mRNA expression of proapoptotic and antiapoptotic genes observed in the present study suggested that $M$. zeylanica exerts its antiproliferative effects, at least partly, via apoptosis; however, the underlying mechanism of apoptosis may differ between the three cancer cell lines investigated.

Oxidants are able to damage DNA and cause mutations, which may lead to carcinogenesis, and are additionally able to stimulate cell division (28). Antioxidants reduce oxidative damage to DNA and reduce aberrant increases in cell division (29). The results of the present study demonstrated that the hexane extract of $M$. zeylanica possessed antioxidant ability, as revealed by the observed free radical scavenging activity.

GC-MS analysis of the hexane extract identified that it was rich in sterols and long-chain hydrocarbons. $\beta$-sitosterol and $\beta$-amyrin detected in the hexane extract have been reported to be cytotoxic and apoptosis-inducing compounds in MCF-7 breast cancer cells and HL-60 leukemia cells, respectively (30-32). The $\mathbf{M}_{1}$ fraction was identified to contain 7 unknown compounds. It additionally contained a small number of known compounds that are not cytotoxic. GC-MS profiles of active fractions gave the present study a strong direction for isolation of phytochemicals from the hexane extract, which is currently being investigated in additional studies.

In conclusion, the results of the present study provide confirmatory evidence for the presence of anticancer compounds in $M$. zeylanica, an endemic plant used by traditional practitioners in Sri Lanka for the treatment of cancer. Of the two solvent extracts identified to be cytotoxic (hexane and chloroform extracts), the hexane extract demonstrated a greater cytotoxicity in the three cancer cell lines and reduced cytotoxicity in normal mammary epithelial cells. Furthermore, the hexane extract exerted apoptotic and antioxidant effects. The greater cytotoxic effect exerted by the active fraction, particularly on triple-negative cells, warrants additional studies investigating the anticancer effects of M. zeylanica.

\section{Acknowledgements}

The present study was supported by the National Research Council (Colombo, Sri Lanka; grant no. NRC 11-018).

\section{References}

1. National Breast Cancer Coalition: Ending Breast Cancer: A Baseline Status Report. 2011 Progress Report. National Breast Cancer Coalition, Washington DC, USA, 2011.

2. Rochefort H, Glondu M, Sahla ME, Platet N and Garcia M: How to target estrogen receptor-negative breast cancer? Endocr Relat Cancer 10: 261-266, 2003.

3. Li J,Humphreys K, Darabai H, Rosin G, Hannelius U,Heikkinen T, Aittomäki K, Blomqvist C, Pharoah PD, Dunning AM, et al: A genome-wide association scan on estrogen receptor-negative breast cancer. Breast Cancer Res 12: R93, 2010. 
4. Verma S, Provencher L and Rent R: Emerging trends in the treatment of triple-negative breast cancer in Canada: A survey. Curr Oncol 18: 180-190,2011.

5. Hurvitz SA and Kakkar R: Role of lapatinib alone or in combination in the treatment of HER-2 positive breast cancer. Breast Cancer (Dove Med Press) 4: 35-51, 2012.

6. Foulkes WD, Smith IE and Reis-Filho JS: Triple-negative breast cancer. N Engl J Med 363: 1938-1948, 2010.

7. Coates A, Abraham S, Kaye SB, Sowerbutts T, Frewin C, Fox RM and Tattersall MH: On the receiving end - patient perception of the side-effects of cancer chemotherapy. Eur J Cancer Clin Oncol 19: 203-208, 1983

8. Cragg GM and Newman DJ: Plants as a source of anti-cancer agents. J Ethnopharmacol 100: 72-79, 2005.

9. Weerarathne WAPG, Samarajeewa PK and Nilanthi RMR: Genetic diversity of Etamba in Sri Lanka. Trop Agric Res Ext 8 : 107-112, 2005.

10. Herath P, Karunanayake E, Selliah SS and Wannigama GP: Isolation of mangiferin from the bark of Mangifera zeylanica. Phytochemistry 9: 1141, 1970.

11. Gouveia S, Gonçalves J and Castilho PC: Characterization of phenolic compounds and antioxidant activity of ethanolic extracts from flowers of Andryala glandulosa ssp. Varia (Lowe ex DC). R.Fern an Endemic Species of Macaronesia Region. Indian Crop Prod 42: 573-582, 2013.

12. Zhishen J, Mengcheng T and Jianming W: The determination of flavonoid contents in mulberry and their scavenging effects on superoxide radicals. Food Chem 64: 555-559, 1999.

13. Kokate CK: Practical Pharmacognosy. 4th edition. Vallabh Prakashan, New Delhi, pp107-111, 2005.

14. Raman N (ed): Phytochemical Techniques. 1st edition. New India Publishing Agency, New Delhi, pp19-24, 2006.

15. Chan EW, Soh EY, Tie PP and Law YP: Antioxidant and antibacterial properties of green, black, and herbal teas of Camellia sinensis. Pharmacognosy Res 3: 266-272, 2011.

16. Samarakoon SR, Thabrew I, Galhena PB, De Silva D and Tennekoon KH: A comparison of the cytotoxic potential of standardized aqueous and ethanolic extracts of a polyherbal mixture comprised of Nigella sativa (seeds), Hemidesmus indicus (roots) and Smilax glabra (rhizome). Pharmacognosy Res 2: 335-342, 2010

17. Ribble D, Goldstein NB, Norris DA and Shellman YG: A simple technique for quantifying apoptosis in 96-well plates. BMC Biotechnol 5: 12, 2005.

18. Livak KJ and Schmittgen TD: Analysis of relative gene expression data using real-time quantitative PCR and the $2^{-\Delta \Delta C T}$ method Methods 25: 402-408, 2001.

19. García-Rivera D, Delgado R, Bougarne N, Haegeman G and Berghe WV: Gallic acid indanone and mangiferin xanthone are strong determinants of immunosuppressive anti-tumour effects of Mangifera indica L. bark in MDA-MB231 breast cancer cells. Cancer Lett 305: 21-31, 2011.
20. Sankari SL, Masthan KM, Babu NA, Bhattacharjee T and Elumalai M: Apoptosis in cancer - an update. Asian Pac J Cancer Prev 13: 4873-4878, 2012.

21. Bates DJ and Lewis LD: Manipulating the apoptotic pathway: Potential therapeutics for cancer patients. Br J Clin Pharmacol 76: 381-395, 2013.

22. Pirnia F, Schneider E, Betticher DC and Borner MM: Mitomycin C induces apoptosis and caspase- 8 and -9 processing through a caspase-3 and Fas-independent pathway. Cell Death Differ 9: 905-914, 2002.

23. Elmore S: Apoptosis: A review of programmed cell death Toxicol Pathol 35: 495-516, 2007.

24. Bajt ML, Knight TR, Lemasters JJ and Jaeschke $\mathrm{H}$ : Acetaminophen-induced oxidant stress and cell injury in cultured mouse hepatocytes: Protection by $\mathrm{N}$-acetyl cysteine. Toxicol Sci 80: 343-349, 2004.

25. Findley HW, Gu L, Yeager AM and Zhou M: Expression and regulation of $\mathrm{Bcl}-2, \mathrm{Bcl}-\mathrm{xl}$, and $\mathrm{Bax}$ correlate with p53 status and sensitivity to apoptosis in childhood acute lymphoblastic leukemia. Blood 89: 2986-2993, 1997.

26. Mirza A, McGuirk M, Hockenberry TN, Wu Q, Ashar H, Black S, Wen SF, Wang L, Kirschmeier P, Bishop WR, et al: Human survivin is negatively regulated by wild-type p53 and participates in p53-dependent apoptotic pathway. Oncogene 21: 2613-2622, 2002.

27. Abeysinghe RD, Greene BT, Haynes R, Willingham MC, Turner J, Planalp RP, Brechbiel MW, Torti FM and Torti SV: p53-independent apoptosis mediated by tachpyridine, an anti-cancer iron chelator. Carcinogenesis 22: 1607-1614, 2001.

28. Rahman K: Studies on free radicals, antioxidants, and co-factors. Clin Interv Aging 2: 219-236, 2007.

29. Ames BN, Shigenaga MK and Hagen TM: Oxidants, antioxidants, and the degenerative diseases of aging. Proc Natl Acad Sci USA 90: 7915-7922, 1993.

30. Chai JW, Kuppusamy UR and Kanthimathi MS: Beta-sitosterol induces apoptosis in MCF-7 cells. Malays J Biochem Mol Biol 16: 28-30, 2008.

31. Barros FW, Bandeira PN, Lima DJ, Meira AS, de Farias SS, Albuquerque MR, dos Santos HS, Lemos TL, de Morais MO, Costa-Lotufo LV and Pessoa Cdo Ó: Amyrin esters induce cell death by apoptosis in HL-60 leukemia cells. Bioorg Med Chem 19: 1268-1276, 2011.

32. Fabiyi OA, Atolani O, Adeyemi OS and Olatunji GA: Antioxidant and cytotoxicity of $\beta$-Amyrin acetate fraction from Bridelia ferruginea leaves. Asian Pac J Trop Biomed 2 (Suppl): S981-S984, 2012. 